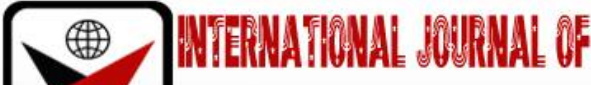

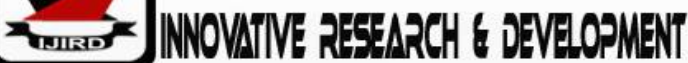

ISSN 2278 - 0211 (Online)

\section{An Examination of Appraisal Techniques -Human Resource Management Use for Upgrading the Employees in Banking Sector in Nigeria}

\author{
Ph.D. Student, Department of Business Administration, City University, Cambodia \\ Dr. Usung Isaac Akpan \\ Senior Lecturer, Department of Human Resource Management, City University, Cambodia
}

Bala Abubakar

\begin{abstract}
:
This research work is an assessment of performance appraisal management human resource managers' use upgrading employees in the banking industry in Nigeria using selected banks. The study was designed to find out the extent Nigerian banks have embraced performance management and to assess the leadership commitment towards the effectiveness of performance management. The population of the study was 283 Staff of Ecobank, Diamond bank, and United Bank for Africa (UBA), Access bank, and First Bank Nigeria in Jimeta Metropolis, Adamawa State. A sample size of 166 was determined through the Taro Yamane formula. Primary data were collected by means of questionnaire which was administered on the managers, supervisors, senior and junior staff of the banks. The data collected were analyzed and interpreted using inferential and descriptive tools. Hypotheses were tested with single sample t-test and simple linear regression. Study discloses that Nigerian banks have embraced performance management significantly and that effective performance management reduces employee turnover and improves service quality. Again, there is a significant, positive relationship between leadership commitment and performance management effectiveness and significant positive relationship between communicating strategy to the staff and performance management. The study therefore recommends that Nigerian banks should invest on their employees and managers so as to drive and consolidate the gains of performance management to remain competitively relevant in the industry.
\end{abstract}

Keywords: Appraisal, employees, banking, performance, human resource

\section{Introduction}

The increased focus on performance at all levels of an organization arises from the pressures and intensity of competition in the business environment and the associated requirement to create a competitive advantage in order to survive in the market place. This scenario brings to focus the role of human resources (HR) which has undergone fundamental changes and it is evolving such functional strategies which enable successful implementation of the major corporate strategies. In a way, HR and corporate strategies function in alignment. Today, HR work towards facilitating and improving the performance of employees by building a conducive work environment and providing maximum opportunities to the employees for participating in organizational planning and decision-making process. It is important to observe that today all the major activities of HR are driven towards the development of high-performance leaders and fostering employee motivation. So, it can be interpreted that the role of HR has evolved from merely an appraiser to a facilitator and an enabler of good environment.

Mayo (2001), Elias and Scarborough (2004) argue that in human capital, the value-creating skills, competencies, talents and abilities of an organization's workforce is an essential component in creating such competitive advantage. Performance management is argued to have a key role in developing such human capital (Tahvavainen, 2000). Walsh, Bryson and Lonti (2002) are of the view that organizational changes arising from competitive pressures have had a great impact on performance management, not least because they have made the use of conventional top-down appraisal system more difficult and led to, for example, the increased use of multi-source feedback (Fletcher, 2001).

The term performance has been defined by many scholars (Drucker,1954; Kohli\& Jaworski,1996; Aluko, 2003; Dauda, 2010). In all, it can be deduced that performance is the efficient and effective use of resources by an organization for the accomplishment of its objective or goal leading to increase in the following: share price, sales, market share, sustainable profitability, productivity, net present value, earnings, generating cash flows, risk taking, leverage and demand for its product or service and satisfying the desired expectations of its three main stakeholders comprising owners, employees and customers. 
Hirsh, Brown, Chubb and Reilly (2011) opine that the history of appraisal systems and their evolution into performance management systems can be compared to the telling and re-telling of an epic saga. They further observe that performance management has become a key process in the eyes of HR professionals that the function is tempted to put more and more things it would like to address into the process. The shift in terminology from performance appraisal to performance management was intended to make the process more relevant to business. The increased competitive nature of the economy and rapid change in the external environment has forced many organizations to shift from reactive performance appraisals to the proactive performance management to boost productivity and improve organizational performance (Nayab and Richter, 2011). Toppo and Prusty (2012) observe that day-to- day corporate environment is becoming more competitive and comprehensive. For survival and competition in the market environment organizations need competent employees who can face present and uncertain future challenges, hence, organizations always try to seek new ways to improve their employee's performance. Traditionally, this objective was attempted to be achieved through employee performance appraisal which was more concerned with telling employees where they lacked in their performance. Though performance appraisal served the purpose to some extent, it was not considered enough to raise the employee performance to the most desirable level.

\subsection{Statement of the Problem}

It has been noted that Nigerian banks have embraced globalization, ICT, intensive competition and reliance on employees as key assets for coping with the changing needs of the environment and excelling in the business of building up their adaptive capacities for managing change proactively. It is also observed that the traditional performance appraisal system does not meet the needs of the changing scenarios as it was mainly used as a tool for employee evaluation in which the managers were impelled to subjective judgments about the performance and behaviour of the employees against the predetermined job standards. The aspect of performance that has to do with outcomes or behaviour is very important in the life of an employee in the services of the Nigerian banks. This is because it provides the strongest linkage to the strategic goals of organization, customer satisfaction, and economic contributions. Nigerian banks as profit oriented organisations cannot avoid looking away from the performance of their employees if they will be able to thrive in the global economic environment. As a result, effective management of the performance of their employees becomes a necessary condition for their survival.

Knowing the method adopted by Nigerian banks in managing employee performance is necessary - is it based on the old order of appraisal or the new order of management? If it is the new order, to what extent have they embraced performance management? Are there change signs resulting from the adoption of performance management in the Nigerian banks? To what extent has the leadership of Nigerian banks committed themselves to the new order?

\subsection{Objectives of the Study}

This study aims at assessing performance management adoption in the banking industry in Nigeria. In addition, the study seeks to achieve the following specific objectives:

- To assess the extent at which Nigerian banks have embraced performance management.

- To identify the change signs in Nigerian banks as a result of adoption of performance management.

- To assess the extent of leadership commitment towards the effectiveness of performance management;

- To examine if failure in communicating the strategy to staff makes performance management ineffective.

\subsection{Research Hypotheses}

The following hypotheses stated in their null forms were tested in the course of this study:

- Ho: Nigerian banks have not embraced performance management significantly.

- Ho: Effective performance management does not reduce employee turnover and improved service quality in Nigerian banks.

- Ho: There is no significant positive relationship between leadership commitment and performance management effectiveness in Nigerian banks.

- Ho: There is no significant positive relationship between communicating strategy to staff and performance management effectiveness in Nigerian banks.

\subsection{Scope of the Study}

The study covered five deposit money banks in Nigeria: Ecobank, Diamond bank, and United Bank for African (UBA), Access bank and First Bank. The branches of these banks in Jimeta Metropolis were involved in the study. The following categories of staff formed the respondents to the study: the branch managers, supervisors, senior and junior staff of the banks.

\section{Review of Related Literature}

\subsection{Definition of Performance Management}

The underlying concept of performance management has become an issue of central and critical concern to political leaders, public and private sector managers (Bouckaer and Hilligan, 2008; Larbi, 2006; Mupazviriho, 2003; Radin, 2006; Varma, Budhwar and Devisi, 2008). This is a concept in the field of human resources management (HRM) like many social science concepts that defy single acceptable definitions performance management has been variously defined, depending on the person discussing it and the context. Its elusiveness has led many to resort to describing, rather than 
defining it (Frank, 2009; Halachmi, 2005; Heinrich, 2007; Radin, 2006). It has been argued that what necessitates the performance management system is the increased focus on performance at all levels in an organization arising from the pressure of competitive advantages and globalisation in the present market scenario. It is the key process through which work is accomplished; it is considered the 'Achilles Heel' of managing human capital (Pulakos, 2009). Simply, implementing a performance management system itself will not fix any performance issues nor will it instantly motivate employees to better performance (Coleman, 2009; Pachsiry, 2011). Managing performance has been a very important issue; some authors have seen it as a means that assist organisation to link organizational goals to individual's goal (Dessler, 2005; Williams, 2002; Pachsiry, 2011). Consequently, Lucas, Lupton and Mathiesan (2006) see it to be concerned with: How people work, how they are managed and developed to improve their performance, and ultimately and how to maximize their contribution to the organization.

\subsection{Performance Management Process}

Lucas, Lupton \& Maithesan (2006) argue that there lies no universal model of performance management, however, that a review of literature and practice suggests that there are a number of elements which might typically be found in a performance management system. These elements are often depicted as a performance cycle (IDS, 2003).

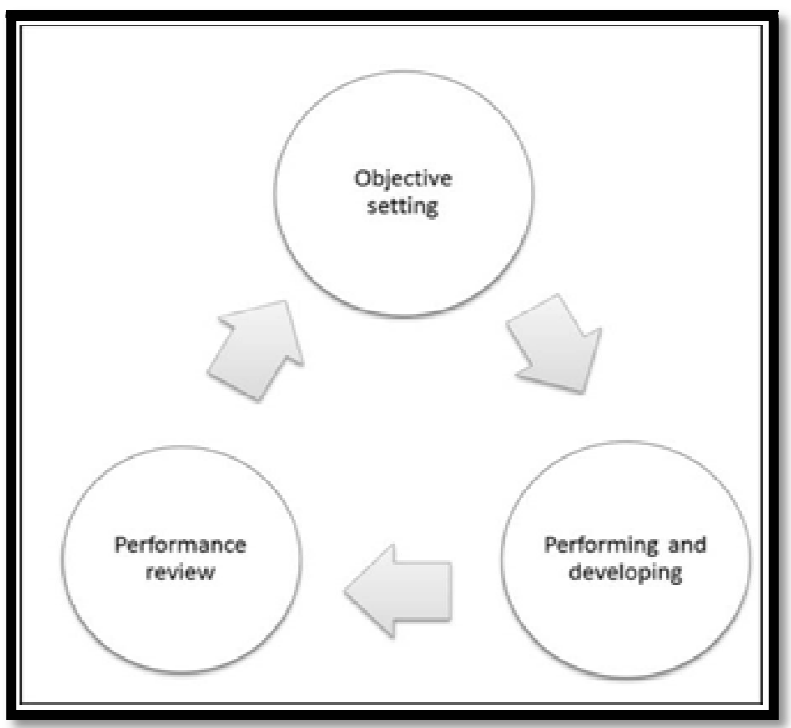

Figure 1: Typical Performance Management Cycle

Source: Lucas R., Lupton, B. and Mathiesan H. (2006), Human Resources

Management in an International Context: CIPD

Pulakos (2004) posits that based on examination of performance management processes in several organizations, most contain some variation of the process shown below:

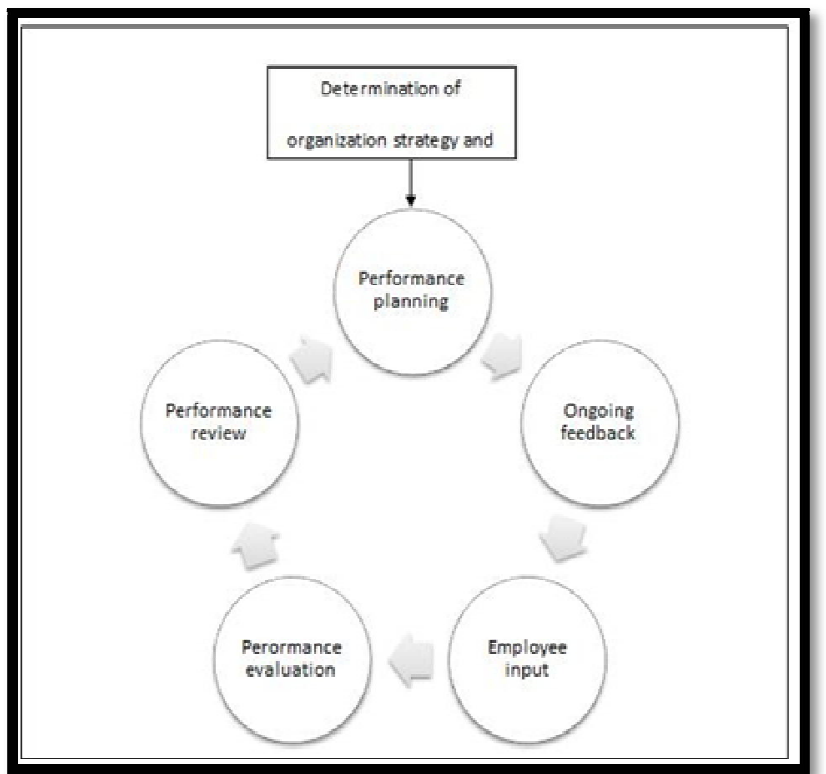

Figure 2: Typical Performance Management Process

Source: Pukalos, E.D (2009). Performance Management: A New Approach for Driving Business Results, Malden, M.A: Wiley- Blackwell 
It is important to observe that in the two figures presented above, the emphasis is virtually the same; it will be expedient we merge the two so as to form a common front of what constitutes the typical performance management process. Objectives setting and performance planning relate, performing and developing envelops ongoing feedback and employee input whereas performance review is made up of performance evaluation and performance review. The emphasis of Lucas, Lupton \&Matheison (2006) and Pulakos (2004) is one and the same.

\subsection{Theoretical Framework of the Study}

Lucas, Lupton and Mathiesan (2006) succinctly observe that the underlying theoretical foundation for performance management lies in motivation theory and, in particular, goal setting theory and expectancy theory. Goal setting theory (Locke and Latham, 2002) suggests that not only does the assignment of specific goals result in enhanced performance but that assuming goal acceptance, increasing the challenges or difficulty of goals leads to increased motivation and increases performance (Mitchell, Thompson and George-Falvy, 2000). Expectancy theory infers that individuals change their behaviour according to their anticipated satisfaction in achieving certain goals (Vroom, 1964). Both of these theories have important implications for the design of performance management processes. It is very important we state that for this study the theoretical framework shall be anchored on the motivation theory, and in particular, goal setting theory. Locke and Latham (2002) stated that a goal drives performance. It affects direction, effort and persistence of employees. Specifically, a goal directs an employee's attention toward actions which bring goal accomplishment, leads an employee to adjust and persists their efforts and stimulates the development of task strategist to attain it. This study therefore hinges on these theories.

\subsubsection{Empirical Review}

It is pertinent to observe that many studies have been conducted to assess the impact of performance management on the employee's performance and/or related subject in general. Adekoya, Oluseye and Kingsley (2014) carried out a study on 'Performance Appraisal in the Nigerian banking Sector: the individual and joint variables Analyses'in a sample of 195respondents drawn from banks with branches in Ado Ekiti. The data obtained were analyzed using regression analysis and F-Statistics for the hypotheses testing. They discovered that sound management of Performance Appraisal (PA) system will guarantee good employee productivity and a very strong and positive relationship exists between performance appraisal and employee productivity. The study concludes that, for Nigerian banks to earn sound employees' performance, a conscious effort towards an improved performance appraisal system is required. It is important to recall that performance appraisal system is an integral part of performance management.

Idemobi and Onyeizugbe (2011) in their study 'performance management as an imperative for effective performance inDelta State of Nigerian public owned organization', sought to identify the effects of performance review techniques on employees' performance; to ascertain if there is a significant relationship between performance incentives and employees' morale. Data were collected using questionnaire administered to forty-four (44) respondents selected from five (5) public organizations in Delta State. Data obtained were analysed using statistically summarization techniques and chi-square at 0.05 level of significance for empirical testing of the hypotheses. The result showed that performance review techniques have significant effect on employees' performance. The study also found that there is a significant relationship between performance incentives and employees' morale. Based on the findings, the study concludes that the absence of performance management system will contribute to the high rate of business failures in the Delta State public sector.

In another study by Pachsiry (2011), 'performance management effectiveness in Thai banking industry: a look from performers and a role of interactional justice'. Data were collected from 476 employees in the four largest banks in Thailand. The results from structural equation analyses support hypothesized model that attitudes towards performance evaluation directly relate to perceived performance effectiveness and interactional justice mediates the coachingperformance management effectiveness. It also found that linkage between consequences and targeted performance is positively related to coaching. Thus, the result suggests that although performance management and performance evaluation are not the same, employee's attitudes towards performance evaluation can highly affect their attitudes towards performance management effectiveness.

Bowra, Sharif, Saeed, and Niazi (2012) studied 'Impact of human resource practices on employee perceived performance in banking sector of Pakistan.' The survey of 235 banking personnel examined the relationship and nature of relationship between the employee's perceived performance and human resource (HR) practices (compensation, performance evaluation, and promotion practices) in the banking sector of Pakistan. The analyses were done using the Spearman's correlation matrix and multiple regressions. The Spearman's correlation results demonstrate that, the employee perceived performance and HR practices has the positive and significant relationship. The regression results indicate that the two HR practices: performance evaluation and promotion practices are significant but the compensation practices are not significant. Moreover, this study provides help for top-management of banking sector to design or revise their HR policies and make practices to attain high employee performance.

Muhammad and Surayya (2013) in their 'performance appraisal and employees' motivation: a comparative analysis of telecom industry in Pakistan' explored the connection between what employees perceived about performance appraisal and what impact their perception has on their work motivation in telecom sector of Pakistan. They used responses collected from 120 respondents, data were analysed with the use of regression and ANOVA. They found significant relationships between variables. Perceived fairness is found as a critically important dimension of performance appraisal for employee motivation in telecom sector of Pakistan. The results can be a source of policy formulation and its implications for improving the process of performance appraisal in this sector of Pakistan as well as in other developing 
countries. In a study involving 30 employees of ICCI Bank India, Devina and Gupta (2012) aimed at finding out the factors contributing to effectiveness of performance management system. Simple regression and component pacts analyses were used. The study revealed that clarity of goals and clarity of job description (communication) have significant impact on the effectiveness of performance management system.

Again, Fareed (2012) used correlation analysis to investigate the relationship between performance management system and employee performance. The key dimensions of performance management system (job description, clear objective performance appraisal, reward and recognition) were found to have strong positive relationship with job performance. The study of Ali, Faheen and Faiza (2014) which involved 7 staff of Alfalah Bank used oral interview to investigate the effectiveness of performance management system in the bank. The study revealed that the impact of performance management system was not felt in the bank, thereby leading to job dissatisfaction, poor motivation among others.

Although few studies have carried out in this area of study on the Nigerian banks, none sought to ascertain the extent of adoption, the change signs resulting from it as well as the nature of bank leadership commitment to it. This study tries to close this gap by focusing on the five banks identified

\section{Research Methodology}

The study applied the survey approach using structured questionnaire. Internal records of the five banks show that our target population; branch managers, supervisors, senior and junior staff of the banks within Jimeta metropolis, Adamawa State, Nigeria was two hundred and eighty-three (283). A sample size of one hundred and sixty-six (166) was derived with the use of Yamane (1973) formula. The study made use of the Cronbach Alpha to arrive at a value of 0.802 for the test of reliability. The research instrument was equally validated by other experts. The data collected were analyzed using both the descriptive and inferential statistics; particularly one sample t-test and simple regression were used for the hypotheses testing.

\subsection{Data Presentation and Analysis}

\begin{tabular}{|c|c|c|c|c|c|c|}
\hline Bank & Copies & Retrieved and & Percentage of & Lost & Percentage of & Total \\
\hline & Issued & Used & Used & & Lost & \\
\hline Ecobank & 24 & 24 & 14.91 & 0 & 0.00 & 24 \\
\hline Diamond & 39 & 36 & 22.36 & 3 & 60.00 & 39 \\
\hline UBA & 44 & 43 & 26.71 & 1 & 20.00 & 44 \\
\hline Access & 12 & 12 & 07.45 & 0 & 0.00 & 12 \\
\hline First Bank & 47 & 46 & 28.57 & 1 & 20.00 & 47 \\
\hline Total & 166 & $161(97 \%)$ & 100.00 & $5(3 \%)$ & 100.00 & 166 \\
\hline
\end{tabular}

Table 1: Distribution and Retrieval of Instrument

Table 1 shows that out of the total of 166 copies of the questionnaires issued, 161 (97\%) were retrieved and used, while 5 (3\%) were lost. Further analysis was based on the 161 copies retrieved and used.

\begin{tabular}{|c|c|c|c|c|c|c|c|c|}
\hline Statement & SA & $\mathbf{A}$ & $\mathbf{U}$ & D & SD & $\mathbf{T}$ & Mean & STD \\
\hline $\begin{array}{c}\text { All employees are familiar with the } \\
\text { organizations goals and are allowed to align } \\
\text { them to individual goals }\end{array}$ & 46 & 31 & 2 & 8 & 4 & & & \\
\hline $\begin{array}{l}\text { I have a clear job Description and } \\
\text { performance standards are clearly defined. }\end{array}$ & 67 & 13 & 0 & 10 & 1 & & & \\
\hline $\begin{array}{l}\text { Targets are set for activities to be achieved } \\
\text { in a given period. }\end{array}$ & 83 & 5 & 0 & 3 & 0 & & & \\
\hline $\begin{array}{l}\text { Constructive feedback on performance } \\
\text { appraisal is provided on a regular basis. }\end{array}$ & 34 & 42 & 5 & 7 & 4 & & & \\
\hline $\begin{array}{l}\text { My organization documents the progress } \\
\text { Related to performance standard for all } \\
\text { targets. }\end{array}$ & 27 & 33 & 29 & 2 & 0 & & & \\
\hline $\begin{array}{l}\text { Information from performance evaluation } \\
\text { can provide needed input for employee } \\
\text { development. }\end{array}$ & 72 & 08 & 02 & 06 & 03 & & & \\
\hline $\begin{array}{c}\text { Results on performance evaluation link to } \\
\text { Reward of individual and motivates } \\
\text { employees to perform better. }\end{array}$ & 55 & 30 & 4 & 02 & 0 & & & \\
\hline Total & 384 & 162 & 42 & 38 & 12 & 1.845 & 4.36 & 154.63 \\
\hline Percentage & $60 \%$ & $25 \%$ & $7 \%$ & $6 \%$ & $2 \%$ & & & \\
\hline
\end{tabular}

Table 2: Analysis of Responses Relating to the Adoption Of Performance Management in the

Banks (Responses from Junior and Senior Staff Only (1-7) 
Table 2 shows that $384(60 \%)$ responses were generated from the junior and senior staff who strongly agreed that their banks have fully embraced performance management. 162 (25\%), 42 (7\%), 38 (6\%) and 12 (2\%) votes were recorded for agree, undecided, disagree and strongly disagree respectively.

\begin{tabular}{|c|c|c|c|c|c|c|c|c|}
\hline Statement & SA & A & U & D & SD & T & Mean & StD \\
\hline $\begin{array}{l}\text { Employees in my Organization Experience } \\
\text { A reduced degree of dissatisfaction arising } \\
\text { From performance appraisal. }\end{array}$ & 29 & 32 & 17 & 8 & 5 & & & \\
\hline $\begin{array}{l}\text { Employee turnover are Thoroughly } \\
\text { minimized in my organization because of } \\
\text { effective performance management. }\end{array}$ & 40 & 10 & 09 & 30 & 2 & & & \\
\hline $\begin{array}{l}\text { The tendency of employees in my } \\
\text { Organization to raising Their Voices Against } \\
\text { customers/colleagues and neglect } \\
\text { of responsibilities is Highly reduced. }\end{array}$ & 63 & 20 & 01 & 2 & 6 & & & \\
\hline $\begin{array}{l}\text { In my organization, Employee } \\
\text { performance is on the increase. }\end{array}$ & 72 & 19 & 0 & 0 & 0 & & & \\
\hline $\begin{array}{c}\text { The quality of service delivery in } \\
\text { my organization is encouraging. }\end{array}$ & 75 & 15 & 0 & 0 & 1 & & & \\
\hline $\begin{array}{c}\text { Customer satisfaction is a top } \\
\text { priority in my bank. }\end{array}$ & 68 & 23 & 0 & 0 & 0 & & & \\
\hline $\begin{array}{c}\text { errors associated } \\
\text { appraisal is vith } \\
\text { perye } \\
\text { minimal in my organization. }\end{array}$ & 23 & 21 & 4 & 13 & 30 & & & \\
\hline Total & 370 & 120 & 31 & 53 & 41 & & & \\
\hline Percentage & $60 \%$ & $19 \%$ & $5 \%$ & $9 \%$ & $7 \%$ & 1.947 & 4.16 & 141.97 \\
\hline
\end{tabular}

Table 3: Analysis of Responses Relating To Change Signs Resulting From Performance Management Adoption

Table 3 shows that $370(60 \%)$ responses were generated from the junior and senior staff who strongly agreed on the surveyed change signs resulting from performance management adoption in their firms. 120 (19\%), 31 (5\%), 53 (9\%) and 44 (7\%) votes were recorded for agree, undecided, disagree and strongly disagree respectively.

\begin{tabular}{|c|c|c|c|c|c|c|c|c|}
\hline Statement & SA & $\mathbf{A}$ & $\mathbf{U}$ & D & SD & $\mathbf{T}$ & Mean & StD \\
\hline $\begin{array}{l}\text { Supervisor(s) encourage me to } \\
\text { use different ways to improve } \\
\text { my performance. }\end{array}$ & 59 & 21 & 0 & 0 & 01 & & & \\
\hline $\begin{array}{l}\text { Employees participate in goal } \\
\text { alignment and identifying their } \\
\text { career development needs. }\end{array}$ & 33 & 40 & 7 & 8 & 3 & & & \\
\hline $\begin{array}{l}\text { Appropriate efforts are exerted } \\
\text { In the training and } \\
\text { development of employees to } \\
\text { ensure effective performance. }\end{array}$ & 81 & 10 & 0 & 0 & 0 & & & \\
\hline $\begin{array}{l}\text { Supervisor(s) Communicate } \\
\text { expectation clearly, provided } \\
\text { feedback and suggestion } \\
\text { performance management. }\end{array}$ & 42 & 22 & 05 & 15 & 7 & & & \\
\hline $\begin{array}{l}\text { Leadership in my bank buy-in, } \\
\text { drives the processand make } \\
\text { performance } \\
\text { Integral management an } \\
\text { organization. }\end{array}$ & 36 & 28 & 2 & 20 & 5 & & & \\
\hline \begin{tabular}{ll}
\multicolumn{2}{c}{ Leaders recognize and reward } \\
performance & appropriately in
\end{tabular} & 61 & 30 & 0 & 0 & 0 & & & \\
\hline
\end{tabular}




\begin{tabular}{|c|c|c|c|c|c|c|c|c|}
\hline $\begin{array}{l}\text { My organization } \\
\text { resources to ensure } \\
\text { employees and managers own } \\
\text { the system. }\end{array}$ & 19 & 12 & 60 & 9 & 0 & & & \\
\hline $\begin{array}{lccc}\text { The } & \text { Resources } & \text { of } & \text { the } \\
\text { organization } & \text { Are } & & \text { committed } \\
\text { thoroughly } & \text { To } & & \text { enhancing } \\
\text { performance } & & \text { and } & \text { its } \\
\text { management. } & & & \end{array}$ & 25 & 20 & 15 & 21 & 10 & & & \\
\hline Total & 347 & 183 & 89 & 73 & 26 & 2.528 & 4.05 & 127.20 \\
\hline Percentage & $48 \%$ & $28 \%$ & $12 \%$ & $10 \%$ & $4 \%$ & & & \\
\hline
\end{tabular}

Table 4: Analysis of responses relating to Leadership Commitment to Performance Management

Table 4 shows that $347(48 \%)$ responses were generated from the junior and senior staff who strongly agreed that the leadership of their banks are committed to performance management.183 (28\%), 89 (12\%), $73(10 \%)$ and 26 (4\%) votes were recorded for agree, undecided, disagree and strongly disagree respectively.

\begin{tabular}{|c|c|c|c|c|c|c|c|c|}
\hline Statement & SA & A & $\mathbf{U}$ & $\mathbf{D}$ & SD & $\mathbf{T}$ & Mean & StD \\
\hline $\begin{array}{l}\text { Communicate howthe results of the } \\
\text { employee's work contributes to the } \\
\text { unit/organizations goals. }\end{array}$ & 33 & 26 & 0 & 8 & 3 & & & \\
\hline $\begin{array}{l}\text { Generate what information, resources, } \\
\text { tools training and supervisor from the } \\
\text { employee. }\end{array}$ & 40 & 20 & 02 & 04 & 04 & & & \\
\hline $\begin{array}{l}\text { Provide ongoing performance feedback } \\
\text { to prevent problem from arising. }\end{array}$ & 70 & 0 & 0 & 0 & 0 & & & \\
\hline $\begin{array}{l}\text { Provide ongoing performance feedback } \\
\text { to employees to recognize excellent } \\
\text { performance. }\end{array}$ & 52 & 15 & 0 & 02 & 01 & & & \\
\hline $\begin{array}{l}\text { Work with the employees to remove } \\
\text { barriers to success and identify } \\
\text { strategies to minimize barriers. }\end{array}$ & 41 & 20 & 5 & 13 & 4 & & & \\
\hline $\begin{array}{l}\text { Gather feedback information from other } \\
\text { sources - customer input, workplace } \\
\text { survey, peer feedback, etc. }\end{array}$ & 36 & 12 & 5 & 13 & 4 & & & \\
\hline $\begin{array}{c}\text { The manager/supervisor communicates } \\
\text { with the employees during the work } \\
\text { period about job tasks, to prevent } \\
\text { problem and keep current. }\end{array}$ & 70 & 0 & 0 & 0 & 0 & & & \\
\hline Total & 402 & 100 & 8 & 32 & 18 & 1,508 & 4.49 & 166.05 \\
\hline Percentage & $72 \%$ & $18 \%$ & $1.4 \%$ & $6 \%$ & $3 \%$ & & & \\
\hline
\end{tabular}

Table 5: Analysis of Responses Relating to Communication of Strategy and Performance Management (Responses from Managers and Supervisors 4 - 11) 
Table 5 shows that 402 (72\%) responses were generated from the supervisors and managers who strongly agreed that the communication strategy of their banks in performance management is effective.100 (18\%), $8(1 \%)$, $32(6 \%)$ and $18(3 \%)$ votes were recorded for agree, undecided, disagree and strongly disagree respectively.

\subsection{Test of Hypotheses}

\begin{tabular}{|c|c|c|c|c|c|}
\hline Hypothesis & TValue Cal & Sig Value & T Critical & Alpha & Decision \\
\hline One & 4.787 & 0.000 & 1.648 & 0.05 & Reject Null \\
\hline
\end{tabular}

Table 6

- Interpretation: At 0.05 level of significance, $\mathrm{df}(90)$ and test value 4, the one sample t-test shows the value of $\mathrm{p}$ (sig. 2 tailed) $=0.000$ and $t$ value $=4.787$.

- Decision: Since the calculated $t$ value (4.787) is greater than $t$ critical (1.648) and the p value (0.000) is less than alpha (0.05), we therefore reject the Null hypothesis and accept the alternative hypothesis which states that Nigerian banks have embraced performance management significantly.

\begin{tabular}{|c|c|c|c|c|c|c|c|c|}
\hline Hypotheses & R & R2 & Adjusted R & DW & P-Value & Fcal & Fcritica & Decision \\
\hline Two & 0.993 & 0.985 & 0.980 & 2.122 & 0.001 & 200.53 & 6.39 & Reject Null \\
\hline Three & 0.934 & 0.872 & 0.830 & 2.903 & 0.20 & 20.48 & 6.39 & Reject Null \\
\hline Four & 0.995 & 0.991 & 0.988 & 2.064 & 0.000 & 325.38 & 6.39 & Reject Null \\
\hline
\end{tabular}

- Interpretation: Performance management is positively and significantly related to not reduction of employee turnover, communication of strategy to staff and leadership commitment. In other words, these variables are significant correlates of performance management. The dependent variable and the three independent variables are highly fitted $\left(\mathrm{R}^{2}=99.1 \%, 87 \%\right.$ and $\left.99 \%\right)$ and the overall regression is significant $(\mathrm{F}=200,20$ and 325). Also, the DW tests show that the residuals from the linear regression are independent, while there is no first order linear autocorrelation in the simple regression data. Since the value follows between $1.5<\mathrm{d}<2.5$ and they tend to be closer to 4 as against 0 .

- Decision: Since F-values calculated are greater than F critical (6.39) and the p- values $(0.001,0.20$ and 0.000$)$ are less than alpha(0.05), we therefore reject the Null hypotheses and accept the alternative hypotheses which states that there is a significant relationship between leadership commitment, reduced employee turnover as well as communication strategy to staff and performance management effectiveness.

\section{Summary and Discussion of Findings}

The findings of the study are presented as follows:

- With respect to research question one; it was found that the selected Nigerian banks have embraced the adoption of performance management. The reflection of the extent of adoption is shown by the mean score of 4.36 from table 4.3 and 4.49 from table 4.7. These high mean scores of strongly agreed is an implied degree of the adoption of performance management by the selected banks (Tcal (.4.787) >Tcritical (1.648) with p-value of 0.000). This finding is in line with the studies of Adekoya, Oluseye and Kingsley (2014), who discovered that most bank in Ado Ekiti apply performance management strategies; it is also supported by Fareed (2012) and Ali, Faheen and Faiza (2014).

- It was found out that effective performance management reduced employee turnover and improved service quality in the Nigerian banks (Fcal. (200.53) >Fcritical (6.39) with p-value of 0.001). This finding is in line with the studies of Adekoya, Oluseye and Kingsley (2014), Idemobi and Onyeizugbe (2011), Fareed (2012), and Ali, Faheen and Faiza (2014).

- It was found out that there was significant positive relationship between leadership commitment and performance management effectiveness (Fcal.(20.48)>Fcritcal(6.39) with the p-value of 0.020). The finding is in agreement with the studies Lock and Lathan (2002), Fareed (2012) and Ali, Faheen and Faiza (2014).

- Finally, the study equally found out that there was a significant relationship between communication of strategy to staff of Nigerian banks and performance management effectiveness (Fcal. (325.38)>Fcritical (6.39) with pvalue (0.000)). This is in line with the findings of Pachsiry (2011) and Muhammad and Surayya (2013).

\section{Conclusion and Recommendations}

Based on the findings, the following recommendations are made:

- For Nigerian banks to realize the full potential benefits from the performance management system, the organizations must be prepared to invest resources on their employees and managers so that they can 'own' the 
system, otherwise it will be treated as compliance activity. The employees need to understand what performance management is for, how it is going to work, what to expect, and what will be expected of them.

- Nigerian banks should not view its performance management system as a cost, but as an investment in the organizations future. When the organization commits to making the necessary investment, the benefits that organization can realize is substantial. Effective performance management processes serve a critical function in communication expectations to employees, providing ongoing feedback and coaching, and in some cases addressing performance issues.

- Nigerian banks should ensure that employees' goals are aligned with the organization business goals and be consistent with the organization mission and /or vision statement. This is because successful results are achievable if all members of the organization team know and share strategic goals and know how to achieve their individual goals.

- $\quad$ Nigerian banks need to continuously improve quality of their services, attract more customers and become more cost-conscious.

\section{References}

i. Adekoye, A. O., Oluseye, S. A. \& Kingsley, K. A. (2014). Performance appraisal in the Nigerian banking sector: The individual and joint variables analyses. European Journal of Business and Management, 6(5), 140-147.

ii. Ali, S. S., Falveen, M., \& Faiza, A. (2014). Investigating the effectiveness of performance management in Alfalah bank. Journal of Public Administration and Government, 2(2), 24-39.

iii. Aluko, M. A. 0. (2003). The impact of culture on organisational performance in selected textile firms in Nigeria.Nordic Journal of African Studies, 12(2), 164-179.

iv. Anyanwu, C. M. (2010). An overview of current banking sector reforms and the real sector. Central Bank of Nigeria, Economic and Financial Review, 48(4).

v. Bouckaert, G., \& Halligan, J. (2008). Managing Performance: International Comparisons. London: Routledge.

vi. Bowra, Z. A., Sharif, B., Saeed, A., \& Niazi, M. K. (2012). Impact of Human Resource Practice on Employee PerceivedPerformance in Banking Sector of Pakistan. African Journal of Business Management, 6 (1), $323-332$.

vii. Bristcoe, D. R., \& Claus, M. (2008). Employee performance management: policies and practices in multinational enterprises, in A. Varma, P. S. Budhwar \& A. DeNisi (ed.). Performance Management Systems: A Global Perspective. London: Routledge.

viii. Coleman, T. (2009). Performance Management. Recommendations for Implementation of Performance Management Systems in Organisations. University of Wollongong, New South Wales, Australia.

ix. Dauda, Y. A. (2010). Employee's Market Orientation and Business Performance in Nigeria: Analysis of Small Business Enterprises in Lagos State. International Journal of Marketing Studies, 2(2),1918-7203.

x. Dessler, G. (2005). Human Resource Management. In upper Saddle River, NJ: Pearson Prentice Hall.

xi. Dessler, G. (2008). Human resources management. New Jersey: Pearson Prentice Hall.

xii. Devina, U., \& Gupta, A. (2012) 'Efficacy of Performance Management System: An Empirical Study at ICCI Bank' International Journal of Advanced Research in Management and Social Sciences, 1(3).

xiii. Drucker, P.F (1954). The Practice of Management. New York: Harper \& Row Inc.

xiv. Elias, J., \& Scarbrough, H. (2004), Evaluating human Capital: An exploratory study of management practice. Journal of Human Resource Management, 14(4), 21-40.

xv. Fareed, H. M. (2012). Performance management system and job performance of employees: Case study of workers of Meezan bank, Lahore Pakistan. Unpublished Master's dissertation at the University of Utali, Malasia.

xvi. Fletcher, C. (1993). Appraisal routes to improve performance. London: Institute of Personnel Management.

xvii. Fletcher, C. (2001). Performance appraisal and Management: The developing research agenda. Journal of Occupational \& Organisational Psychology, 74, 473-87.

xviii. Fletcher, C., \& Williams, R. (1996). Performance management, job satisfaction and organisational commitment. British Journal of Management 7(2), 169-179.

xix. Frank, L. K. O. (2009). Constraints in the implementation of performance management systems in developing countries: The Ghanaian case. International Journal of Cross Cultural Management, 9(1), 109-132.

xx. Fryer, K., Anthony, J., \& Ogden, S. (2009). Performance management in the public sector. International Journal of Productivity and Performance Management, 22(6), 478-498.

xxi. Furnham, A. (2004). Performance management systems. European Business Journal, 16, 83-94.

xxii. Glendining, P. M. (2002). Performance management: Pariah or Messiah. Public Personnel Management, 31, 161178.

xxiii. Glenn, D. I. (2013). Determining sample size. The Institute of Food and Agriculture Sciences (IFAS) Extension, University of Florida.

xxiv. Graham, J. (2004). Developing a performance-based culture. Journal for Quality \& Participation, 27, 4-8.

xxv. Greer, R. (2001). Strategic human resource management: A general managerial approach (2nd ed.). London: Prentice-Hall.

xxvi. Halachmi, A. (2005). Performance Measurement: Test the Water before the Dive in. International Review of Administrative Science, 71(2), 255-66.

xxvii. Hamlin, R., Ellinger, A., \& Beattie, R. (2006). Coaching of heart at the managerial effectiveness: A cross cultural study of managerial behaviours. Human Resources Development International, 9(3), 305-331. 
xxviii. Harris, L. (2001). Human resource management: When research confronts theory. The International Journal of Human Resource Management, 12, 1092-1106.

xxix. Hassan, D. A., \& Shakel, S. (2010). Improving performance management practices in IT firms of Pakistan.

xxx. Heinrich, C. J. (2007). Measuring public sector performance \& Effectiveness: In B. G. Peters \& J. Pierre (eds). The Handbook of Public Administration. London: Sage.

xxxi. Hetcher, C., \& Williams, R. (1996). Performance management, job satisfaction and organizational commitment. British Journal of Management, 7(2), 169-179.

xxxii. Hirsh, W., Brown, D., Chubb, C., \& Reilly, P. (2011). Performance management: The implementation challenge key research finding. Institute for Employment Studies HR Network Paper MP89. www.employment.studies.co.uk/ publications.

xxxiii. Idemobi, E. I., \& Onyeizugbe, C. (2011). Performance management as an imperative for effective performance in Delta State of Nigerian public owned organizations. Sacha Journal of Policy and Strategic Studies, 1(2), 46-54.

xxxiv. Kohli, A. K., \& Jaworski, B. J. (1996). Market orientation: Review, refinement and roadmap. Journal of Marketing\& Focused Management, 1(2), 119-135.

xxxv. Larbi, G. A. (2006). Applying the new public management in developing countries. In Y. Bangura \& G. A. Larbi (eds). Public sector reforms in developing countries: Capacity challenges in improve services. Hampshire: Palmgrove.

xxxvi. Lawson, P. (1995). Performance management: An overview. In Walters, M. The Performance Management Handbook. London: Institute of Personnel and Development.

xxxvii. Levy, P., \& Williams, J. (2004). The social context of performance appraisal: A review and framework for the future. Journal of Management, 30(6), 881-995.

xxxviii. Lindbom, D. (2007). A Culture of Coaching: The Challenge of Managing Performance for Long-term results. Organisation Development Journal, 25(2): 101-106.

xxxix. Lucas, R., Lupton, B., \&Mathiesan, H. (2006). Human resources management in an international context. United Kingdom: CIPD.

xl. Mann, G. A. (2006). A motive to service: Public service motivation in human resource management and the role of PMS in the nonprofit sector. Public Personnel Management, 35(1), 33-48

xli. Marko, S. (2011). 10 reasons why performance management fails and how to remedy them. Adapted from integrated performance management system. Regenesys.co.za/2011/03/10

xlii. Martinez, V., \&Kennerley, M. (2006). Performance management. NY: Financial management, 32-33.

xliii. Mayo, A. (2001). The Human Value of the Enterprise: Valuing People as Assets-Monitoring, Measuring, Managing. London: Nicolas Brealey.

xliv. McDonald, D., \& Smith, A. (1995). A proven connection: Performance management \& business results. Compensation and Benefits Review, 27(1), 59-62.

xlv. Megha, O., \&Paresh, R. (2013). What your performance management system needs most. India: SHRM.

xlvi. Mitchell, T. R., Thompson, K. P., \& Georg-Falvy, J. (2000). Goal-setting theory and practice. In C. L. Cooper \& E. A. Locke (eds) Industrial, work and organizational psychology. Oxford: Sage.

xlvii. Moynihan, D. P. (2008). The dynamics of performance management: Constructing information and reform. Washington, DC: Georgetown University Press.

xlviii. Muhammad, S. M., \& Surayya, A. (2013). Performance appraisal and employees motivation: A comparative analysis of telecom industry in Pakistan. Pakistan Journal of Social Sciences, 33(1), 179-189.

xlix. Mupazviriho, P. (2003). Understanding performance management in the public service. Africa Journal of Public Administration and Management, 14(1), 1-9.

l. Murphy, K. R., \& Cleverland, J. N. (1995). Understanding performance appraisal: Social, organizational and goalbased perspectives. London: Sage Publications.

li. Nakervis, A. R., \& Compton, R. L. (2006). Performance management: theory in practice? Australian Human Resources Institute, 44(1), 83-101.

lii. Pachsiry, C. (2011). Performance management effectiveness in Thai banking industry: A look from performance and role of international justice. Journal of International Business and Cultural Studies, 1-22.

liii. Parker, P., Hall, D., \& Kram, K. (2008). Peer coaching: A relational process for accelerating career learning. Academy of Management Learning \& Education, 7(4), 487-503.

liv. Pickett, L. (2003). Transforming the annual Fiasco, industrial and commercial training. Academy of Management Review, 35 (6), 237-240.

lv. Pukalos, E. D. (2009). Performance management: A new approach for driving business results. London: WileyBlackwell.

lvi. Ramlall, S. (2003). Measuring human resources management's effectiveness in improving performance. Human Resource Planning, 26(1), 51-62.

lvii. Rheem, H. (1996). Performance management programs: Do they make any difference? Harvard Business Review, October 3-4.

lviii. Rubiensak, A., \& Bovaird, T. (1999). Performance management and Organisational Learning, Matching Process to culture in the UK and Chinese Services. International Review of Administrative Science, 65(2), 25-68 